\title{
Serotypes and antimicrobial resistance patterns of Salmonella enterica subsp. enterica in pork and related fresh-vegetable servings among pork outlets in Kampala, Uganda
}

\author{
Dickson Ndoboli $^{1 * *}$ Kristina Roesel ${ }^{2,3 *}$ Martin Heilmann ${ }^{2,3}$ \\ Thomas Alter ${ }^{4}$ Peter-Henning Clausen ${ }^{3}$ Edward Wampande ${ }^{1}$ \\ Delia Grace ${ }^{2}$ Stephan Huehn ${ }^{4}$
}

\begin{abstract}
Keywords
Pork, Salmonella enterica subsp. enterica, resistance to antibiotics, food chain, PCR, Uganda
\end{abstract}

\footnotetext{
Submitted: 19 July 2017

Accepted: 4 June 2018

Published: 9 September 2018

DOI: $10.19182 /$ remvt.31289
}

\begin{abstract}
Summary
The aim of this study was to characterize serotypes, phenotypic antimicrobial resistance patterns, and plasmid profiles of 55 Salmonella enterica subsp. enterica isolates in different matrices from 77 pork outlets in Kampala, Uganda. Seven different serovars were identified, namely Enteritidis (60\%), Offa (10.9\%), Gallinarum (7.3\%), Arechavaleta (monophasic) $(7.3 \%)$, Zanzibar (7.3\%), Kampala $(5.4 \%)$, and Saintpaul $(1.8 \%)$. Most isolates were obtained from raw pork $(40.0 \%)$, followed by flies $(27.3 \%)$, raw vegetables $(18.2 \%)$, water $(12.7 \%)$, and roasted pork (1.8\%). All but one of the isolates $(98 \%)$ showed resistance to at least one of the 22 antimicrobials tested, with highest levels of resistance expressed to cefazolin (95\%), and cefotaxime (93\%). Intermediate resistance was found to ciprofloxacin (58\%), chloramphenicol (58\%), and amoxicillin-clavulanic acid (56\%). Most isolates were susceptible to levofloxacin (75\%), sulfamethoxazole-trimethoprim (80\%), and ofloxacin (96\%). Characterization of strains by PCR-based replicon typing detected the presence of FIA, FIB, FIC, HI1, HI2, I1-1 $\gamma, \mathrm{L} / \mathrm{M}, \mathrm{N}, \mathrm{P}, \mathrm{W}, \mathrm{T}, \mathrm{A} / \mathrm{C}, \mathrm{K}, \mathrm{B} / \mathrm{O}, \mathrm{X}, \mathrm{Y}, \mathrm{F}$ and FIIA replicons. Six replicon groups (FIA, W, FIC, FIB, P, and Y) were identified in 53 of the 55 (96.4\%) isolates with more than one group existing among 42 different isolates. Although the average number of replicon groups per strain was low (2.6), phenotypical resistance rates remained high implying that some strains seemed to encode resistance on the chromosome or undetected plasmids, respectively. Potential drivers in livestock production and human medicine, and sources of antimicrobial resistance need to be identified to protect public health in Uganda.

- How to quote this article: Ndoboli D., Roesel K., Heilmann M., Alter T., Clausen P.-H., Wampande E., Grace D., Huehn S., 2018. Serotypes and antimicrobial resistance patterns of Salmonella enterica subsp. enterica in pork and related fresh-vegetable servings among pork outlets in Kampala, Uganda. Rev. Elev. Med. Vet. Pays Trop., 71 (1-2): 103-109, doi: 10.19182/remvt.31289
\end{abstract}

\section{INTRODUCTION}

The term 'pork joint' refers to small- to medium-size pork outlets serving ready-to-eat pork to consume on site as well as raw pork for home preparation and consumption. They are found along busy trading centers and streets in the suburbs of Kampala, Uganda. In most cases, pork

1. Central Diagnostic Laboratory, Makerere University, Kampala, Uganda.

2. Animal and Human Health Program, International Livestock Research Institute, PO Box 30709, Nairobi, Kenya.

3. Institute for Parasitology and Tropical Veterinary Medicine, Freie Universität Berlin, 14163 Berlin, Germany.

4. Institute of Food Hygiene, Freie Universität Berlin, 14163 Berlin, Germany.

* Corresponding author

Tel.: +254 20422 3409; Email: k.roesel@ cgiar.org

${ }^{* *}$ D. Ndoboli and K. Roesel contributed equally to this work. joints are semi-permanent or permanent wooden stalls that are open from morning until late at night and where clients consume roasted or fried pork (Roesel and Grace, 2014; Heilmann, 2016). Prepared pork meals are usually served along with fresh accompaniments such as finely chopped onions and tomatoes, locally known as kachumbari, green peppers, and avocadoes. Food preparation is done under poor hygienic conditions; flies are common and pork is left out on a table or hanging in an open window to attract clients (Heilmann et al., 2015a). This, along with ambient temperatures between $20^{\circ} \mathrm{C}$ and $37^{\circ} \mathrm{C}$, renders pork prone to contamination with physical and biological hazards.

In general, microbiological food contamination is a major public health concern. The first global assessment of foodborne disease found that more than $80 \%$ of the burden, which is measured in 'disability adjusted life years', was attributed to bacteria, helminths, and protozoa (Havelaar et al., 2015). Food can be contaminated during production or further down the value chain, mostly caused by poor hygiene practices 
(Mensah et al., 2002). Common causes of microbial food-borne disease include non-typhoidal Salmonella (NTS), Salmonella (S.) Typhi, Vibrio cholerae, toxigenic Escherichia coli, Campylobacter spp., norovirus, and Listeria monocytogenes (Mensah et al., 2002; Havelaar et al., 2015). Among the 31 foodborne hazards investigated by the World Health Organization's Foodborne Disease Burden Epidemiology Reference Group, NTS was the most important in terms of overall burden and deaths, especially in African subregions (Havelaar et al., 2015).

Cases of drug-resistant Salmonella spp. have been reported in a number of countries in East Africa (Kariuki et al., 2006; Kikuvi et al., 2010; Omulo et al., 2015) and are likely to increase (Byarugaba, 2004; Sirinavin et al., 2004). Previous studies in Uganda show a high prevalence of multiresistant strains, evidence of cross-species transmission of plasmids, and drug resistance in animals and humans (Kalule et al., 2012; Tinega et al., 2016). Typing methods such as plasmid profiling, ribotyping, and pulsed-field gel electrophoresis have been used to aid diagnosis and outbreak investigation (Lukinmaa et al., 2004).

In a community-based prevalence survey at pork outlets in Kampala S. enterica subsp. enterica was investigated as an indicator pathogen potentially carried onto food products by flies (Heilmann, 2016). Although the prevalence data are presented elsewhere (Heilmann et al., 2015b), the aim of this study was to characterize serotypes, phenotypic patterns of antimicrobial resistance (AMR), and plasmid profiles of the obtained Salmonella isolates.

\section{MATERIALS AND METHODS}

\section{Sample collection}

In a cross-sectional survey, 77 of 179 pork outlets in Kampala were randomly selected and 693 samples from different substrates were collected between June and July 2014 (Heilmann, 2016). Fresh pork samples of 5-10 g were aseptically collected directly from display windows, vegetables and roasted pork samples of 5-10 $\mathrm{g}$ from serving plates, and water samples from storage containers. Hand swabs and utensil swabs were taken from pork handlers' hands and cutlery. Swab samples from flies were obtained from the fly guts wash solution after they had been caught individually with sterile nets and transferred into sterile tubes (Heilmann, 2016). All samples were transported in a box at $4^{\circ} \mathrm{C}$ to the Central Diagnostic Laboratory, Makerere University, Kampala, then kept at $-20^{\circ} \mathrm{C}$ until analysis. Isolation of Salmonella spp. was performed according to ISO 6579:2002.

\section{Bacteriological culture, isolation, and confirmation}

For microbiological investigation, samples were pre-enriched in 10 $\mathrm{ml}$ of $1 \%$ buffered peptone water (Oxoid, Hampshire, UK) and incubated at $37^{\circ} \mathrm{C}$ for $18-24$ hours. A $0.1 \mathrm{ml}$ aliquot of the pre-enrichment was transferred into $9 \mathrm{ml}$ of Rappaport Vassiliadis selective enrichment broth (Oxoid) and incubated at $42^{\circ} \mathrm{C}$ for $18-24$ hours. Then, a loop of inoculum was streaked onto xylose-lysine-deoxycholate agar (Oxoid) and incubated at $37^{\circ} \mathrm{C}$ for 24 hours. Hydrogen sulfide producing colonies were subcultured on fresh xylose-lysine-deoxycholate agar plates. Colonies from subcultures were Gram stained, examined via microscope at $100 \times$ magnification, and subjected to biochemical testing which included methyl red test (Oxoid), indole production test, citrate utilization test (Oxoid), Voges-Proskauer test (Oxoid), dulcitol (Oxoid), and mannitol fermentation test (Oxoid, Hampshire) (Barrow and Feltham, 1993). Isolates that were biochemically positive for $\mathrm{Sal}$ monella enterica were preserved in micro vials on Mueller-Hinton agar for molecular identification. To confirm Salmonella species, a simplex PCR according to Rahn et al. (1992) was performed at the Institute for Food Hygiene of Freie Universität Berlin, Germany. Serotyping was performed at the Food and Agriculture Organization of the United Nations Reference Centre for Veterinary Public Health hosted by Freie Universität Berlin and the National Reference Laboratory for Salmonella hosted by the Federal Institute for Risk Assessment in Berlin, according to Grimont and Weill (2007).

\section{Antimicrobial resistance tests}

Salmonella-positive isolates were subjected to antimicrobial resistance (AMR) tests using the Kirby-Bauer disc diffusion method with Luria-Bertani agar. In total, 22 antimicrobial agents were tested: ampicillin (AP; $10 \mu \mathrm{g}$ ), amoxicillin-clavulanic acid (AMC; 20/10 $\mu \mathrm{g}$ ), ampicillin-sulbactam (SAM; 10/10 $\mu \mathrm{g}$ ), piperacillin (PRL; $100 \mu \mathrm{g}$ ), piperacillin-tazobactam (PTZ; 100/10 $\mu \mathrm{g}$ ), cefazolin $(\mathrm{CZ} ; 30 \mu \mathrm{g})$, cefepime (CPM; $30 \mu \mathrm{g}$ ), cefotaxime (CTX; $30 \mu \mathrm{g}$ ), cefoxitin (FOX; $30 \mu \mathrm{g}$ ), ceftazidime (CAZ; $30 \mu \mathrm{g}$ ), cefuroxime sodium (CXM; $30 \mu \mathrm{g}$ ), cephalothin (KF; $30 \mu \mathrm{g})$, imipenem (IMI; $10 \mu \mathrm{g}$ ), meropenem (MEM; $10 \mu \mathrm{g}$ ), amikacin (AK; $30 \mu \mathrm{g})$, gentamicin (GM; $10 \mu \mathrm{g}$ ), tetracycline (TET; $30 \mu \mathrm{g}$ ), ciprofloxacin (CIP; $5 \mu \mathrm{g}$ ), levofloxacin (LEV; $5 \mu \mathrm{g}$ ), ofloxacin (OFX; $5 \mu \mathrm{g}$ ), chloramphenicol (CHA; $30 \mu \mathrm{g}$ ), and sulfamethoxazole-trimethoprim (SXT; 23/1.25 $\mu \mathrm{g}$ ) (Mast, Bootle, UK). Corresponding brake points were obtained using guidelines set by the Clinical and Laboratory Standards Institute (CLSI, 2012). E. coli and Enterococcus faecalis were used as control strains.

\section{PCR-based inc/rep typing method}

A DNA template was prepared by the Chelex method: three to five $S$. colonies were washed in $500 \mu \mathrm{l}$ of Tris-EDTA buffer and centrifuged at $10,000 \times g$. The pellet was resuspended in $500 \mu \mathrm{l}$ of $5 \%$ Chelex in water and incubated under constant shaking (Eppendorf) for one hour at $56^{\circ} \mathrm{C}, 700 \mathrm{rpm}$, later incubated at $95^{\circ} \mathrm{C}, 700 \mathrm{rpm}$ for $20 \mathrm{~min}$ after which it was centrifuged $10,000 \times g$. Then the supernatant was collected and used for PCR. The PCRs were performed according to Carattoli et al. (2005) in which 18 pairs of primers designed to perform five multiplex and three simplex PCR reactions were used, recognizing the following 18 replicon groups: FIA, FIB, FIC, HI1, HI2, I1-I $\gamma, \mathrm{L} / \mathrm{M}, \mathrm{N}, \mathrm{P}, \mathrm{W}, \mathrm{T}, \mathrm{A} / \mathrm{C}, \mathrm{K}, \mathrm{B} / \mathrm{O}, \mathrm{X}, \mathrm{Y}, \mathrm{F}$, and FIIA.

\section{Data management and analysis}

Data were entered into Microsoft Excel version 10 for descriptive analysis.

\section{Ethical statement}

The research involved obtaining swabs from pork handlers, vegetables, flies, and water. Approval was obtained from the Research and Ethics Committee at the College of Veterinary Medicine, Animal Resources and Biosecurity, Makerere University, Kampala (Ref.: $\mathrm{VAB} / \mathrm{REC} / 14 / 111)$. Informed consent was obtained from each participant included in the study.

\section{RESULTS}

In total, 59 Salmonella isolates were obtained from flies, meat, vegetables, and water and confirmed as S. enterica subsp. enterica by PCR. Four isolates were too weak after transport and did not grow well after reconstitution, so they were omitted from further analysis. The remaining 55 isolates were serotyped and identified as $S$. enterica serovar Enteritidis (33/55; 60.0\%), serovar Offa $(6 / 55 ; 10.9 \%)$, serovar Arechavaleta (4/55; $7.3 \%)$, serovar Gallinarum (4/55; 7.3\%), serovar Zanzibar (4/55; 7.3\%), serovar Kampala $(3 / 55 ; 5.4 \%)$, and serovar Saintpaul (1/55; 1.8\%). Most isolates were obtained from raw pork $(22 / 55 ; 40.0 \%)$, followed by flies $(15 / 55 ; 27.3 \%)$, raw vegetables $(10 / 55 ; 18.2 \%)$, water $(7 / 55 ; 12.7 \%)$, and roasted pork $(1 / 55 ; 1.8 \%)$. None of the samples from the hands of pork handlers or cutlery carried S. enterica. Nineteen of the 22 raw pork isolates (86.4\%) were obtained from Wambizzi abattoir, the only formal pig 
slaughterhouse in Kampala. Details are presented in Table I and in the supplemental material (Supplementary Material I). The AMR profiles of the 55 Salmonella isolates are described in Figures 1 and 2.

The highest level of AMR ( $\geq 80.0 \%)$ was found for CZ (94.5\%), CTX (92.7\%), GM (89.1\%), CAZ (87.3\%), AK (85.5\%), PRL (85.5\%), KF (80.0\%), and CXM (80.0\%). Resistance to TET and CHA was low $(\leq 20.0 \%)$ at $16.4 \%$, and LEV, OFX, and SXT showed very low resistance (1.8\%) (Table II). Resistance was found in isolates from raw pork, followed by isolates from flies. The lowest number of resistant strains was isolated from tomatoes.

The inc/rep typing detected the presence of FIA, W, FIC, P, FIB, and Y replicons in 53 of the 55 (96.4\%) isolates. Two isolates, both $S$. Enteritidis from flies, contained none of the replicons tested. FIA and FIB replicons were identified in isolates from pork; replicon type Y was exclusively identified in isolates from fly midguts and water; replicon type $\mathrm{P}$ was identified in isolates from flies, pork, and water; and replicon types FIC and W were identified in isolates from all sources (Table III).

The most commonly found replicon was W. The FIC replicon of amplicon size 262 bp was present in $74.5 \%$ of the isolates, and $36.4 \%$ of the isolates contained the replicon type FIA of size $462 \mathrm{bp}$ (Tables III to V). Most isolates that showed presence of replicon groups had more than one present, on average 2.6, with four isolates presenting five different replicon groups.

\section{DISCUSSION}

In a community-based survey at pork outlets in Kampala, the prevalence of S. enterica subsp. enterica as an indicator pathogen, potentially carried onto food by flies, was investigated. Whereas the prevalence data has been published elsewhere (Heilmann et al., 2017), the study presented here describes serotypes of different Salmonella isolates from pork outlets in Kampala and their AMR patterns. Seven serovars were identified: $S$. Enteritidis, $S$. Offa, $S$. Arechavaleta, $S$. Gallinarum, $S$. Zanzibar, $S$. Kampala and $S$. Saintpaul. Our findings are partly in agreement with the results of a pig farm survey (Ikwap et al., 2014) that reported $S$. Zanzibar and $S$. Kampala including other serovars that we did not report here. However, findings presented here differ from the serovars reported by Tinega et al. (2016) who identified $S$. Paratyphi, $S$. Abony, $S$. Newport, $S$. Bovismorbificans, $S$. Bareilly, $S$. Thompson, $S$. Dublin, and $S$. Typhimurium in pork and pig feces from the Kampala pig abattoir by PCR in 2012. Raw pork and flies were shown to contain salmonellae, mainly $S$. Enteritidis, a serovar pathogenic to a wide range of hosts including humans. This may suggest that pork is contaminated during transport from the slaughterhouse or that Salmonella serotypes are specific to the environment of markets where pork is sold. At Kampala pork outlets, meat is purchased raw for home preparation and consumption (Heilmann et al., 2016), therefore, potentially exposing handlers and consumers to risk of infection with $S$. Enteritidis.

Multidrug resistance was found in $98 \%$ of our isolates; this was much higher than those of $57 \%$ and $54 \%$ reported by Ikwap et al. (2014),
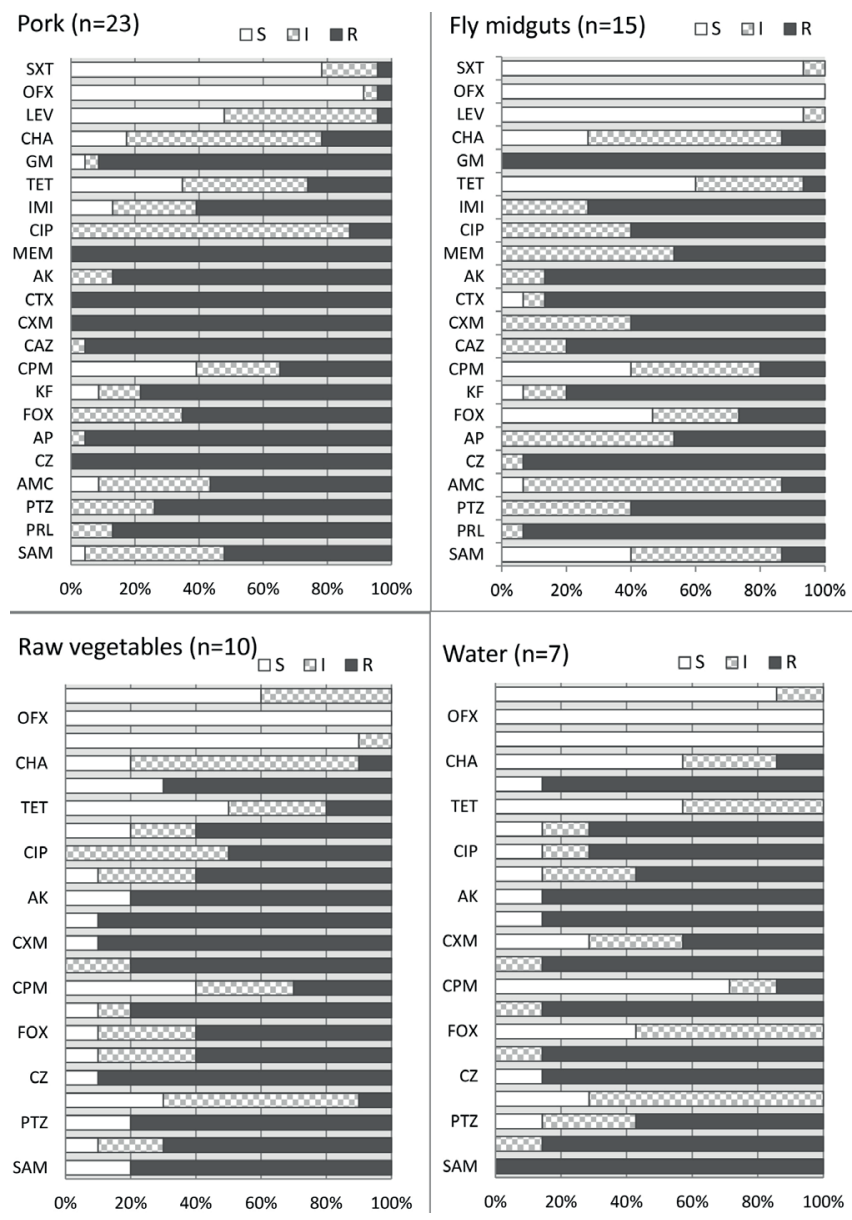

Figure 1: Levels of susceptibility of Salmonella enterica subsp. enterica isolates to 22 antimicrobials in four different types of substrates obtained at pork outlets in Kampala. $S=$ sensitive; $I=$ intermediate; $R=$ resistant

Table I

Salmonella enterica subsp. enterica serotypes identified in different substrates from 77 pork outlets in Kampala, Uganda

\begin{tabular}{lcccccccc} 
Serotype & $\mathbf{n}$ & $\begin{array}{c}\text { Raw pork } \\
(\mathbf{\%})\end{array}$ & $\begin{array}{c}\text { Roasted pork } \\
(\mathbf{\%})\end{array}$ & $\begin{array}{c}\text { Fly midgut } \\
(\mathbf{\%})\end{array}$ & $\begin{array}{c}\text { Cabbage } \\
(\%)\end{array}$ & $\begin{array}{c}\text { Tomato } \\
(\%)\end{array}$ & $\begin{array}{c}\text { Onion } \\
(\%)\end{array}$ & $\begin{array}{c}\text { Water } \\
(\%)\end{array}$ \\
\hline S. Enteritidis & 33 & $19(57.6)$ & $1(3.0)$ & $12(36.4)$ & 0 & $1(3.0)$ & 0 & 0 \\
S. Offa & 6 & 0 & 0 & 0 & $2(33.3)$ & $2(33.3)$ & 0 & $2(33.3)$ \\
S. Arechavaleta & 4 & $3(75.0)$ & 0 & 0 & 0 & 0 & $1(25.0)$ & 0 \\
S. Gallinarum & 4 & 0 & 0 & 0 & $2(50.0)$ & $2(50.0)$ & 0 & 0 \\
S. Zanzibar & 4 & 0 & 0 & $2(50.0)$ & 0 & 0 & 0 & $2(50.0)$ \\
S. Kampala & 3 & 0 & 0 & 0 & 0 & 0 & 0 & $3(100.0)$ \\
S. Saintpaul & 1 & 0 & 0 & $1(100.0)$ & 0 & 0 & 0 & 0 \\
\hline Total & 55 & $22(40.0)$ & $1(1.8)$ & $15(27.3)$ & $4(7.3)$ & $5(9.1)$ & $1(1.8)$ & $7(12.7)$
\end{tabular}




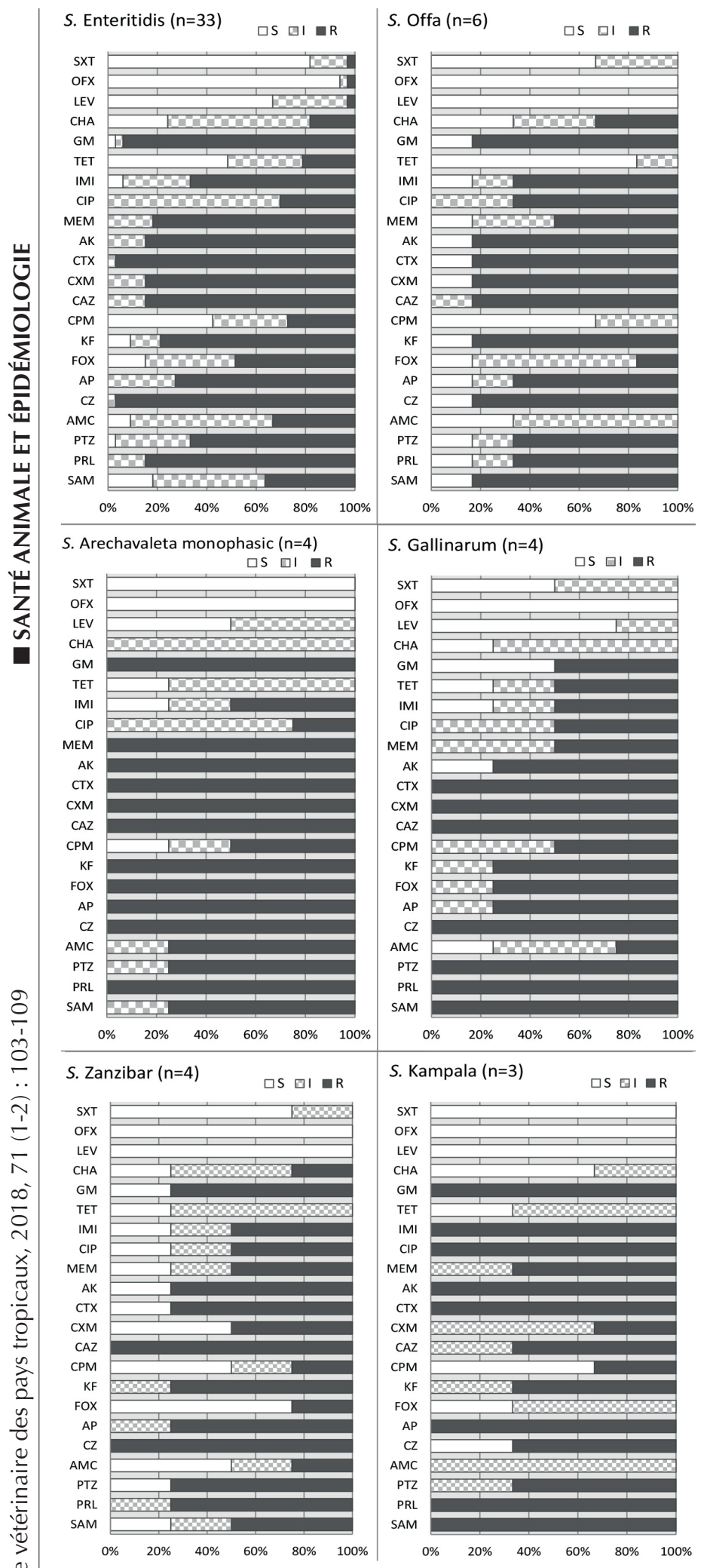

Figure 2: Levels of susceptibility in Salmonella enterica subsp. enterica isolates to 22 antimicrobials obtained at pork outlets in Kampala, presented by serotype. $S=$ sensitive; $I=$ intermediate $R=$ resistant

and Kalule et al. (2012), respectively. However, these differences may be due to the different methodologies used. Whereas we used the disc diffusion method with Luria-Bertani agar, the other authors used Mueller-Hinton agar (both media produced similar results) or broth micro dilution commercial test kits.

\section{Table II}

Distribution of antimicrobial resistance among 55 isolates of Salmonella enterica subsp. enterica obtained at pork outlets in Kampala, Uganda (June-July 2014)

\begin{tabular}{|c|c|c|c|c|}
\hline Antimicrobial & Acronym & $\begin{array}{l}\text { Susceptible } \\
(\%)\end{array}$ & $\begin{array}{c}\text { Intermediate } \\
(\%)\end{array}$ & $\begin{array}{l}\text { Resistant } \\
(\%)\end{array}$ \\
\hline Amikacin & AK & 5.5 & 9.1 & 85.5 \\
\hline $\begin{array}{l}\text { Amoxicillin- } \\
\text { clavulanic acid }\end{array}$ & AMC & 14.5 & 56.4 & 29.1 \\
\hline Ampicillin & AP & 1.8 & 23.6 & 74.5 \\
\hline $\begin{array}{l}\text { Ampicillin- } \\
\text { sulbactam }\end{array}$ & SAM & 16.4 & 30.9 & 52.7 \\
\hline Cefazolin & $\mathrm{CZ}$ & 3.6 & 1.8 & 94.5 \\
\hline Cefepime & CPM & 43.6 & 29.1 & 27.3 \\
\hline Cefotaxime & CTX & 5.5 & 1.8 & 92.7 \\
\hline Cefoxitin & FOX & 20.0 & 34.5 & 45.5 \\
\hline Ceftazidime & CAZ & 0.0 & 12.7 & 87.3 \\
\hline Cefuroxime & CXM & 5.5 & 14.5 & 80.0 \\
\hline Cephalothin & KF & 7.3 & 12.7 & 80.0 \\
\hline Chloramphenicol & $\mathrm{CHA}$ & 25.5 & 58.2 & 16.4 \\
\hline Ciprofloxacin & CIP & 1.8 & 58.2 & 40.0 \\
\hline Gentamicin & GM & 9.1 & 1.8 & 89.1 \\
\hline Imipenem & IMI & 10.9 & 23.6 & 65.5 \\
\hline Levofloxacin & LEV & 74.5 & 23.6 & 1.8 \\
\hline Meropenem & MEM & 3.6 & 23.6 & 72.7 \\
\hline Ofloxacin & OFX & 96.4 & 1.8 & 1.8 \\
\hline Piperacillin & PRL & 1.8 & 12.7 & 85.5 \\
\hline $\begin{array}{l}\text { Piperacillin- } \\
\text { tazobactam }\end{array}$ & PTZ & 5.5 & 25.5 & 69.1 \\
\hline $\begin{array}{l}\text { Sulfamethoxazole- } \\
\text { trimethoprim }\end{array}$ & SXT & 80.0 & 18.2 & 1.8 \\
\hline Tetracycline & TET & 47.3 & 36.4 & 16.4 \\
\hline
\end{tabular}

\section{Table III}

Replicon groups identified by PCR-based typing in 55 Salmonella enterica isolates presented by substrate from 77 pork outlets in Kampala, Uganda

\begin{tabular}{|c|c|c|c|c|c|}
\hline \multirow[b]{2}{*}{$\begin{array}{l}\text { Replicon } \\
\text { group }\end{array}$} & \multirow[b]{2}{*}{$\begin{array}{c}\text { Total } \\
\mathrm{n}=55 \\
(\%)\end{array}$} & \multicolumn{4}{|c|}{ Substrate } \\
\hline & & $\begin{array}{l}\text { Pork } \\
\begin{array}{c}\mathrm{n}=23 \\
(\%)\end{array}\end{array}$ & $\begin{array}{c}\text { Fly } \\
n=15 \\
(\%)\end{array}$ & $\begin{array}{c}\text { Raw } \\
\text { vegetable } \\
\mathrm{n}=10 \\
(\%)\end{array}$ & $\begin{array}{l}\text { Water } \\
n=7 \\
(\%)\end{array}$ \\
\hline FIA & $20(36.4)$ & 18 (78.3) & 0 & $2(20.0)$ & 0 \\
\hline FIB & $10(18.2)$ & $9(39.1)$ & 0 & $1(10.0)$ & 0 \\
\hline FIC & $41(74.5)$ & 19 (82.6) & $9(60.0)$ & $6(60.0)$ & 7 (100.0) \\
\hline P & $19(34.5)$ & $4(17.4)$ & $10(66.7)$ & 0 & $5(71.4)$ \\
\hline W & $42(76.4)$ & $20(87.0)$ & $9(60.0)$ & $8(80.0)$ & $5(71.4)$ \\
\hline Y & $15(27.3)$ & 0 & $10(66.7)$ & 0 & $5(71.4)$ \\
\hline
\end{tabular}

Resistant bacteria in pork may be the result of inappropriate antibiotic use in human medicine or livestock production, and related environmental contamination. However, several studies from Uganda suggest low antimicrobial use in the smallholder backyard farms where most pigs in the country are produced (Dione et al., 2014; Ikwap et al., 
Table IV

Replicon groups identified by PCR-based replicon typing in 55 Salmonella enterica isolates presented by serotype, from 77 pork outlets in Kampala, Uganda

\begin{tabular}{|c|c|c|c|c|c|c|c|c|}
\hline \multirow[b]{2}{*}{$\begin{array}{l}\text { Replicon } \\
\text { group }\end{array}$} & \multirow[b]{2}{*}{$\begin{array}{c}\text { Total } \\
\mathrm{n}=55 \\
(\%)\end{array}$} & \multicolumn{7}{|c|}{ Serotype } \\
\hline & & $\begin{array}{c}\text { S. Enteritidis } \\
\mathrm{n}=33 \\
(\%)\end{array}$ & $\begin{array}{c}S . \text { Offa } \\
n=6 \\
(\%)\end{array}$ & $\begin{array}{c}\text { S. Arechavaleta } \\
\mathrm{n}=4 \\
(\%)\end{array}$ & $\begin{array}{c}\text { S. Gallinarum } \\
n=4 \\
(\%)\end{array}$ & $\begin{array}{c}\text { S. Zanzibar } \\
\mathrm{n}=4 \\
(\%)\end{array}$ & $\begin{array}{c}\text { S. Kampala } \\
\mathrm{n}=3 \\
(\%)\end{array}$ & $\begin{array}{c}\text { S. Saintpaul } \\
n=1 \\
(\%)\end{array}$ \\
\hline FIA & $20(36.4)$ & $17(51.5)$ & $1(16.7)$ & $1(25.0)$ & $1(25.0)$ & 0 & 0 & 0 \\
\hline FIB & $10(18.2)$ & $8(24.2)$ & 0 & $1(25.0)$ & $1(25.0)$ & 0 & 0 & 0 \\
\hline $\mathrm{FIC}$ & $41(74.5)$ & $25(75.8)$ & $4(66.7)$ & $3(75.0)$ & $2(50.0)$ & $4(100.0)$ & $3(100.0)$ & 0 \\
\hline$P$ & $19(34.5)$ & $12(36.4)$ & $2(33.3)$ & 0 & 0 & $3(75.0)$ & $1(33.3)$ & 100.0 \\
\hline W & $42(76.4)$ & $26(78.8)$ & $5(83.3)$ & $1(25.0)$ & $4(100.0)$ & $4(100.0)$ & $1(33.3)$ & 100.0 \\
\hline Y & $15(27.3)$ & $8(24.2)$ & $2(33.3)$ & 0 & 0 & $3(75.0)$ & $1(33.3)$ & 100.0 \\
\hline
\end{tabular}

\section{Table V}

Replicon groups of Salmonella enterica isolates obtained from pork outlets in Kampala, Uganda, between June and July 2014

\begin{tabular}{|c|c|c|c|c|c|}
\hline Isolate No. & Serovar & Replicon group & Isolate No. & Serovar & Replicon group \\
\hline 1 & S. Enteritidis & FIA W FIC & 29 & S. Arechavaleta & $\mathrm{FIC}$ \\
\hline 2 & S. Enteritidis & FIA W FIC & 30 & S. Gallinarum & W FIC \\
\hline 3 & S. Arechavaleta & FIC & 31 & S. Gallinarum & W \\
\hline 4 & S. Arechavaleta & FIC & 32 & S. Offa & W \\
\hline 5 & S. Enteritidis & FIA W FIC & 33 & S. Offa & W \\
\hline 6 & S. Enteritidis & W FIC & 34 & S. Offa & WY P FIC \\
\hline 7 & S. Enteritidis & FIA W FIC & 35 & S. Offa & WY P FIC \\
\hline 8 & S. Enteritidis & FIA W FIC & 36 & S. Zanzibar & WY P FIC \\
\hline 9 & S. Enteritidis & FIA W FIC & 37 & S. Zanzibar & WY P FIC \\
\hline 10 & S. Enteritidis & FIA W FIC & 38 & S. Kampala & $\mathrm{FIC}$ \\
\hline 11 & S. Enteritidis & FIA W FIC & 39 & S. Kampala & $\mathrm{FIC}$ \\
\hline 12 & S. Enteritidis & FIA W FIC & 40 & S. Kampala & WY P FIC \\
\hline 13 & S. Enteritidis & W FIC & 41 & S. Enteritidis & WY P FIC \\
\hline 14 & S. Enteritidis & FIC & 42 & S. Enteritidis & Y P FIC \\
\hline 15 & S. Enteritidis & FIA FIB W P FIC & 43 & S. Enteritidis & Y P FIC \\
\hline 16 & S. Enteritidis & FIA FIB W P FIC & 44 & S. Enteritidis & Y P FIC \\
\hline 17 & S. Arechavaleta & FIA FIB W & 45 & S. Enteritidis & W P FIC \\
\hline 18 & S. Enteritidis & FIA FIB W P FIC & 46 & S. Enteritidis & WY P FIC \\
\hline 19 & S. Enteritidis & FIA FIB W FIC & 47 & S. Enteritidis & Y \\
\hline 20 & S. Enteritidis & FIA FIB W & 48 & S. Zanzibar & WY P FIC \\
\hline 21 & S. Enteritidis & FIA FIB W P FIC & 49 & S. Enteritidis & - \\
\hline 22 & S. Enteritidis & FIA FIB W & 50 & S. Zanzibar & W FIC \\
\hline 23 & S. Enteritidis & FIA FIB W & 51 & S. Enteritidis & WY P FIC \\
\hline 24 & S. Gallinarum & W FIC & 52 & S. Enteritidis & WYP \\
\hline 25 & S. Gallinarum & FIA FIB W & 53 & S. Enteritidis & - \\
\hline 26 & S. Enteritidis & W FIC & 54 & S. Enteritidis & W \\
\hline 27 & S. Offa & FIA FIC & 55 & S. Saintpaul & WY P \\
\hline 28 & S. Offa & W FIC & & & \\
\hline
\end{tabular}

2014). The resistance observed in our study could also be the result of intensively produced livestock systems such as poultry production in Uganda where antimicrobials are commonly used (Thamlikitkul, 1988; Fagbule and Kalu, 1995; McGregor, 1997; Planta, 2007), and where chicken droppings are used as fertilizer or supplement for animal feeds, including pigs. In Uganda, some drugs like gentamicin, piperacillin, and cefazolin - which have all been used in this study - are listed for use in both veterinary and human medicine in the National Drug Register (www.nda.or.ug) and these showed some of the highest levels of resistance. Interestingly, drugs such as ceftazidime, cefuroxime, cefotaxime, meropenem, and amikacin, which are not licensed for veterinary use in Uganda, expressed even 
higher levels of resistance. On the other hand, drugs such as tetracycline which are accessible to most pig farmers showed very low resistance. This may suggest that antimicrobials used in human medicine may enter the value chain at production level, i.e. illegal treatment or supplementation of animals destined for food production.

This is the first study to use replicon typing in analyzing for presence of replicon groups in Salmonella isolates in Uganda. The study by Kalule et al. (2012) used plasmid extraction to characterize plasmids from Salmonella isolates and reported the presence of five plasmids and several strains harboring more than one plasmid. The present study showed similar trends because of the detection of multiple replicon groups. FIC and W replicon groups were spread among isolates from different samples and environmental origin, which suggests the presence of shared groups among S. enterica serotypes from different environments. Moreover, transfer of these replicon groups by a bacterial agent might be possible as well. Thus, the results suggest the presence of recurrent and common groups in epidemiologically unrelated Salmonella isolates of different sources. Since the presence of several replicons per plasmid was reported by Couturier et al. (1988) the number of replicon groups present did not refer to respective plasmids. However, many different replicon groups were found which showed the diversity of strains in this study.

According to Carratoli et al. (2005), the presence of these plasmids is associated with strA-strB and tet(A) resistance genes. These genes encode for streptomycin-inactivating enzymes, they are distributed worldwide and they confer streptomycin resistance in Gram-negative bacteria (Sundin and Bender, 1996). The FIA, FIB, FIC, W, P, and $\mathrm{Y}$ replicon groups identified in the isolates found in this study might contribute to the multidrug resistance in addition to the selection pressure in the environment as a result of increased antibiotic usage from human activities. The recent study, however, tested solely the presence of the replicon groups along with phenotypic resistances without tracing the encoding plasmids. Further studies investigat8 ing which plasmid encoding which antibiotic-resistance gene are needed.

\section{- CONCLUSION}

We presented here the findings from the first study on AMR in Salmonella from pork outlets in Kampala, Uganda. The study characterized the serotypes, generated evidence on emerging AMR in Uganda, and described the major plasmid replicon types that might have contributed to the increase in AMR among Salmonella isolates derived from pork and the environment in the capital of Uganda. Future research should focus on source attribution of S. enterica, for instance the role of raw vegetables, drivers of AMR, e.g. irrational drug use in human or veterinary medicine, and possible points of entry of AMR into the food chain, either through the environment, at animal production, slaughter, or food preparation.

\section{Acknowledgments}

This research was carried out with the financial support of the Federal Ministry for Economic Cooperation and Development, Germany, through the Safe Food, Fair Food project ILRI, the CGIAR Research Program on Agriculture for Nutrition and Health, led by the International Food Policy Research Institute, and the CGIAR Research Program on Livestock and Fish, led by ILRI. The authors thank Ms. Herlinde Irsigler at the Food and Agriculture Organization of the United Nations Reference Centre for Veterinary Public Health at Freie Universität Berlin for her excellent technical assistance in serotyping the isolates, Ms. Tezira Lore, communication specialist at ILRI, for proof-reading the manuscript, and Mr. Michel Dione at ILRI for proofreading the French summary.

\section{REFERENCES}

Barrow G.I., Feltham R.K.A., Eds., 1993. Cowan and Steel's Manual for the identification of medical bacteria, 3rd Ed. Cambridge University Press, Cambridge, UK, 333 p., doi: 10.1017/CBO9780511527104

Byarugaba D.K., 2004. A view on antimicrobial resistance in developing countries and responsible risk factors. Int. J. Antimicrob. Agents, 24 (2): 105-110, doi: 10.1016/j.ijantimicag.2004.02.015

Carattoli A., Bertini A., Villa L., Falbo V., Hopkins K.L., Threlfall E.J., 2005. Identification of plasmids by PCR-based replicon typing. J. Microbiol. Methods, 63 (3): 219-228, doi: 10.1016/j.mimet.2005.03.018

CLSI, 2012. Performance standards for antimicrobial susceptibility testing (Suppl. M100S), 22nd Ed. Clinical and Laboratory Standards Institute; Wayne, PA, USA

Couturier M., Bex F., Bergquist P.L., Maas W.K., 1988. Identification and classification of bacterial plasmids. Microbiol. Rev., 52 (3): 375-95

Dione M.M., Ouma E.A., Lule P., Pezo D., 2014. Animal health services delivery systems and disease surveillance in the smallholder pig value chain in Uganda. In: ICAHS ${ }^{2}$ (2nd Int. Conf. Animal Health Surveillance): Surveillance against the Odds, The Havana, Cuba, 7-9 May 2014, 138-140

Fagbule D., Kalu A., 1995. Case management by community health workers of children with acute respiratory infections: implications for national ARI control programme. J. Trop. Med. Hyg., 98 (4): 241-246

Grimont P.A.D., Weill F.-X., 2007. Antigenic formulae of the Salmonella serovars, 9th Edn. World Health Organization, Paris, France, 167 p.

Havelaar A.H., Kirk M.D., Torgerson P.R., Gibb H.J., Hald T., Lake R.J., Praet N., et al., 2015. World Health Organization global estimates and regional comparisons of the burden of foodborne disease in 2010. PLOS Med., 12 (12): e1001923, doi: 10.1371/journal.pmed.1001923

Heilmann M., 2016. Flies as vectors for Salmonella spp. and their control in pork butcheries in Kampala, Uganda. A contribution to improve public health. Doct. Thesis, Freie Universität, Berlin, Germany, 95 p.

Heilmann M., Mtimet N., Roesel K., Grace D., 2015a. Assessing Ugandan pork butchers' practices and their perception of customers' preferences: A best-worst approach. In: 9th Eur. Congr. Tropical Medicine and International Health, Basel, Switzerland, 6-10 Sept. 2015

Heilmann M., Ndoboli D., Roesel K., Grace D., Huehn S., Bauer B., Clausen P.-H., 2015b. Occurrence of Salmonella spp. in flies and foodstuff from pork butcheries in Kampala, Uganda. In: Annu. Expert meeting on parasitology and parasitic diseases at the German Veterinary Association, Stralsund, Germany, 29 June - 1 July 2015

Heilmann M., Roesel K., Clausen P.-H., Grace D., 2016. Knowledge, attitudes and practices among customers at pork butcheries in Kampala, Uganda. In: First joint conf. AITVM-STVM, Berlin, Germany, 4-8 Sept. 2016

Heilmann M., Roesel K., Grace D., Bauer B., Clausen P.-H., 2017. The impact of insecticide-treated material to reduce flies among pork outlets in Kampala, Uganda. Parasitol. Res., 116 (6): 1617-1626. doi: 10.1007/ s00436-017-5450-x

Ikwap K., Erume J., Owiny D.O., Nasinyama G.W., Melin L., Bengtsson B., Lundeheim N., et al., 2014. Salmonella species in piglets and weaners from Uganda: prevalence, antimicrobial resistance and herdlevel risk factors. Prev. Vet. Med., 115 (1-2): 39-47, doi: 10.1016/j. prevetmed.2014.03.009

Kalule J.B., Kaddu-Mulindwa D.H., Asiimwe B.B., 2012. Antimicrobial drug resistance and plasmid profiles of Salmonella isolates from humans and foods of animal origin in Uganda. Adv. Infect. Dis., 2 (4): 151-155, doi: 10.4236/aid.2012.24025

Kariuki S., Revathi G., Kariuki N., Kiiru J., Mwituria J., Muyodi J., Githinji J.W., et al., 2006. Invasive multidrug-resistant non-typhoidal Salmonella infections in Africa: zoonotic or anthroponotic transmission? J. Med. Microbiol., 55 (Pt 5): 585-591, doi: 10.1099/jmm.0.46375-0

Kikuvi G.M., Ombui J.N., Mitema E.S., 2010. Serotypes and antimicrobial resistance profiles of Salmonella isolates from pigs at slaughter in Kenya. J. Infect. Dev. Ctries, 4 (4): 243-248, doi: 10.3855/jidc.446

Lukinmaa S., Nakari U.-M., Eklund M., Siitonen A., 2004. Application of molecular genetic methods in diagnostics and epidemiology of food-borne bacterial pathogens. APMIS, 112 (11-12): 908-929, doi: 10.1111/j.16000463.2004.apm11211-1213.x 
McGregor A., 1997. Counterfeit drugs flood developing world. Lancet, 350 (9092): 1690, doi: 10.1016/S0140-6736(05)64302-4

Mensah P., Yeboah-Manu D., Owusu-Darko K., Ablordey A., 2002. Street foods in Accra, Ghana: how safe are they? Bull. World Health Organ., 80 (7): 546-554

Omulo S., Thumbi S.M., Njenga M.K., Call D.R., 2015. A review of 40 years of enteric antimicrobial resistance research in Eastern Africa: what can be done better? Antimicrob. Resist. Infect. Control, 4 (1): 1, doi: 10.1186/ s13756-014-0041-4

Planta M.B., 2007. The role of poverty in antimicrobial resistance. J. Am. Board Fam. Med., 20 (6): 533-539, doi: 10.3122/jabfm.2007.06.070019

Rahn K., De Grandis S.A., Clarke R.C., McEwen S.A., Galán J.E., Ginocchio C., Curtiss III R., et al., 1992. Amplification of an invA gene sequence of Salmonella typhimurium by polymerase chain reaction as a specific method of detection of Salmonella. Mol. Cell. Probes, 6 (4): 271-279, doi: 10.1016/0890-8508(92)90002-F
Roesel K., Grace D., Eds., 2014. Food safety and informal markets: Animal products in sub-Saharan Africa. Routledge, London, UK, 284 p.

Sirinavin S., Pokawattana L., Bangtrakulnondh A., 2004. Duration of nontyphoidal Salmonella carriage in asymptomatic adults. Clin. Infect Dis., 38 (11): 1644-1645, doi: 10.1086/421027

Sundin G.W., Bender C.L., 1996. Dissemination of the $\operatorname{str} A-\operatorname{str} B$ streptomycin-resistance genes among commensal and pathogenic bacteria from humans, animals, and plants. Mol. Ecol., 5 (1): 133-143, doi: 10.1111/j.1365-294X.1996.tb00299.x

Thamlikitkul V., 1988. Antibiotic dispensing by drug store personnel in Bangkok, Thailand. J. Antimicrob. Chemother., 21 (1): 125-131, doi: 10.1093/jac/21.1.125

Tinega G.M., Magiri E., Kinyua J., Njahira M., Erume J., Ejobi F., Tegule S., et al., 2016. Characterization of Salmonella isolates obtained from pigs slaughtered at Wambizzi abattoir in Kampala, Uganda. J. Agric. Sci. Technol., 17 (1): 99-120

\section{Résumé}

Ndoboli D., Roesel K., Heilmann M., Alter T., Clausen P.-H., Wampande E., Grace D., Huehn S. Sérotypes et profils de résistance aux antibiotiques de Salmonella enterica subsp. enterica présente dans le porc et les légumes frais servis dans les points de vente de Kampala, Ouganda

L'objectif de l'étude était de caractériser les sérotypes et les profils phénotypiques de résistance aux antibiotiques, et de typer les plasmides de 55 isolats de Salmonella enterica subsp. enterica isolés dans différentes matrices provenant de 77 points de vente de porc à Kampala, en Ouganda. Sept différents serovars ont été identifiés : Enteritidis (60,0\%), Offa $(10,9 \%)$, Gallinarum $(7,3 \%)$, Arechavaleta (monophasique) $(7,3 \%)$, Zanzibar (7,3\%), Kampala (5,4\%), et Saintpaul $(1,8 \%)$. La majorité des isolats provenaient de porc cru $(40,0 \%)$ mais on en trouvait aussi dans des mouches $(27,3 \%)$, des légumes frais $(18,2 \%)$, de l'eau $(12,7 \%)$ et du porc grillé $(1,8 \%)$. Tous les isolats sauf un $(98 \%)$ ont montré une résistance à au moins un antibiotique parmi les 22 testés. Le plus haut niveau de résistance a été observé avec la céfazoline $(95 \%)$ et le céfotaxime (93\%), un niveau intermédiaire a été observé avec la ciprofloxacine (58\%), le chloramphénicol (58\%) et I'amoxicilline/acide clavulanique (56\%). La majorité des isolats étaient sensibles à la lévofloxacine (75\%), au sulfaméthoxazole-triméthoprime $(80 \%)$ et à l'ofloxacine $(96 \%)$. La caractérisation des souches par le typage des réplicons, une technique basée sur la PCR, a détecté les réplicons FIA, FIB, FIC, HI1, HI2, I1-1 $\gamma$, L/M, N, P, W, T, $A / C, K, B / O, X, Y, F$ et FIIA. Six groupes de réplicons (FIA, W, $\mathrm{FIC}, \mathrm{FIB}, \mathrm{P}$, and $\mathrm{Y}$ ) ont été identifiés dans 53 des 55 isolats $(96,4 \%)$, et plus d'un groupe a été trouvé dans 42 isolats différents. Alors que le nombre moyen de groupes de réplicons par souche était bas $(2,6)$, le taux de résistance phénotypique est resté élevé, ce qui implique que certaines souches semblent encoder des résistances sur les chromosomes ou sur les plasmides non détectés, respectivement. Les sources de résistance aux antibiotiques ainsi que les causes potentielles liées aux systèmes d'élevage et à la médecine humaine doivent être identifiées pour protéger la santé publique en Ouganda.

Mots-clés : viande porcine, Salmonella enterica subsp. enterica, résistance aux antibiotiques, chaîne alimentaire, PCR, Ouganda

\section{Resumen}

Ndoboli D., Roesel K., Heilmann M., Alter T., Clausen P.-H., Wampande E., Grace D., Huehn S. Patrones de resistencia antimicrobiana y serotipos de Salmonella enterica subsp. enterica en cerdos y raciones relacionadas de vegetales frescos en ventas en Kampala, Uganda

El objetivo del estudio fue de caracterizar serotipos, patrones fenotípicos de resistencia antimicrobiana y perfiles de plásmidos de 55 aislamientos de Salmonella enterica subsp. enterica en diferentes matrices de 77 ventas de cerdo en Kampala, Uganda. Se identificaron siete serotipos diferentes, a saber Enteritidis $(60 \%)$, Offa (10,9\%), Gallinarum (7,3\%), Arechavaleta (monophasic) $(7,3 \%)$, Zanzibar (7,3\%), Kampala (5,4\%), y Saintpaul $(1,8 \%)$. La mayoría de los aislamientos fueron obtenidos a partir de carne de cerdo cruda $(40,0 \%)$, seguido de moscas $(27,3 \%)$, vegetales crudos $(18,2 \%)$, agua $(12,7 \%)$ y cerdo asado $(1,8 \%)$. Todos los aislamientos excepto uno $(98 \%)$ mostraron resistencia a por lo menos uno de los 22 antimicrobianos examinados, con los mayores niveles de resistencia expresados a cefazolina (95\%) y cefotaxima (93\%). Se encontró resistencia intermedia en ciprofloxacina $(58 \%)$, cloranfenicol $(58 \%)$ y amoxicilina-ácido clavulánico (56\%). La mayoría de los aislamientos fueron susceptibles a levofloxacina (75\%), sulfametoxazol-trimetoprima $(80 \%)$ y ofloxacina. La caracterización de cepas mediante tipificación de replicones basada en PCR detectó la presencia de replicones FIA, FIB, FIC, HI1, HI2, I1-1 $\gamma$, L/M, N, P, W, T, A/C, K, B/O, X, Y, F y FIIA. Seis grupos de replicones (FIA, W, FIC, FIB, $\mathrm{P}$, and $\mathrm{Y}$ ) fueron identificados en 53 de los 55 (96,4\%) aislamientos, con más de un grupo presente en 42 aislamientos diferentes. Aunque el número promedio de grupos de replicones por cepa fue bajo $(2,6)$, la tasa de resistencia fenotípica permaneció alta, implicando que algunas cepas parecen codificar resistencias en los cromosomas o plásmidos no detectados, respectivamente. Con el fin de proteger la salud pública en Uganda, deben identificarse guías potenciales en la producción ganadera, medicina humana y fuentes de resistencia antimicrobiana.

Palabras clave: carne de cerdo, Salmonella enterica subsp. enterica, resistencia a los antibíoticos, cadena alimentaria, PCR, Uganda 
